\title{
PHARMACY
}

\section{ANALYSIS OF THE STATE OF THE SUPPLY OF UKRAINIAN POPULATION WITH CHONDROPROTECTIVE MEDICATIONS}

\author{
Nemchenko A. S., doctor of Pharmacy (Dr. habil.), professor \\ Nazarkina V. M., candidate of Pharmacy $(P h D)$, associate professor \\ Lebedyn A. M., candidate of Pharmacy $(P h D)$, teaching assistant \\ Podkolzina M. V., candidate of Pharmacy $(P h D)$, associate professor \\ Ukraine, Kharkiv, \\ National University of Pharmacy, Department of Organization and Economics of Pharmacy
}

DOI: https://doi.org/10.31435/rsglobal_wos/31012020/6886

\begin{abstract}
ARTICLE INFO
Received: 15 November 2019

Accepted: 09 January 2020

Published: 31 January 2020

\section{KEYWORDS}

osteoarthrosis,

arthrosis,

locomotor system,

chondroprotectors,

glucosamine,

chondroitin sulfate.

ABSTRACT

Conduct systematic analysis of the state of the supply of Ukraine with medications with chondroprotective activity. The Unified Clinical Protocol of Primary, Secondary (specialized) Medical Care allows doctors to control the state of a patient at every stage of illness and guarantees the effective treatment and prophylaxis of the locomotor system (LMS) pathologies.

As a result of the chondroprotective medication range analysis it was determined that the pharmaceutical market of Ukraine is represented by 40 trade names of medications. The top market share of chondroprotective medications in Ukrainian market belongs to the foreign producers $(52.5 \%)$, while domestic medications occupy $47.5 \%$. In general the nomenclature of Ukrainian medications is provided by 6 manufacturing companies. Three pharmaceutical companies are the leaders producing 5 names of medications each (12.5\% each): Pharmaceutical company "Zdorovye" (Kharkiv), PrJSC "Fitofarm" (Bakhmut, formerly Artemivsk, Donetsk region), JSC "Farmak" (Kyiv). Out of 40 trade names the medications are mainly produced: as coated tablets -12 medications (30\%), as solutions for injections - 11 items (27.5\%), as capsules -7 (17.5\%), as soft dosage forms -6 medicines (15\%), and powders for oral administration -4 items (10\%) [1].
\end{abstract}

Citation: Nemchenko A. S., Nazarkina V. M., Lebedyn A. M., Podkolzina M. V. (2020) Analysis of the State of the Supply of Ukrainian Population with Chondroprotective Medications. International Academy Journal Web of Scholar. 1(43). doi: 10.31435/rsglobal_wos/31012020/6886

Copyright: (ㅇ 2020 Nemchenko A. S., Nazarkina V. M., Lebedyn A. M., Podkolzina M. V. This is an open-access article distributed under the terms of the Creative Commons Attribution License (CC BY). The use, distribution or reproduction in other forums is permitted, provided the original author(s) or licensor are credited and that the original publication in this journal is cited, in accordance with accepted academic practice. No use, distribution or reproduction is permitted which does not comply with these terms.

Introduction. The locomotor system (LMS) disorders are one of the reasons for the incapacity to work and physical disability of population, causing the impairment of quality of life and bringing about considerable treatment expenses. The LMS pathologies affect people of all age categories all over the world. In 2017 they were the leading reason for disabilities in four out of six regions of the World Health Organization (WHO) (ranking second in the Eastern Mediterranean Region and third in the African Region). Though the LMS disorders incidence increases with age, younger people also tend to suffer from them, often at the age of the most economic activity.

Joint diseases comprise one of the most widely spread LMS pathologies. Inflammatory disorders are dangerous by the fact that they can transform into an irreversible process and might lead to disabilities, to the full or partial incapacity to work, as well as promote the development of comorbid conditions. According to the International Statistical Classification of Diseases and Related 
Health Problems of the 10th revision, among all the LMS disorders osteoarthrosis (OA, M15-M19 by ICD-10) is one of the most widely spread degenerative-dystrophic disorders, which comprises the most complicated socio-economic and medical problem. According to the WHO about $4 \%$ of the population of the Earth suffers from OA, which in $10 \%$ of cases is the actual cause of disabilities. The attack rate of adult population of working age since 2008 has been increasing by an average of $4.3 \%$ yearly - from 80.8 to $91.2 \%$; in the population over working age the growth by $1.9 \%$ has been indicated - from 157.6 to $166.8 \%$ [2, 3].

According to the ICD-10 the terms "osteoarthrosis", "arthrosis", "osteoarthritis" are synonyms and only differ by the local classifications depending on the country where applied. The term "osteoarthrosis" is mainly used in Ukraine, while "osteoarthritis" is more common for Europe and the USA. OA ranks first among the disorders of rheumatic profile (60-80\%) and has a tendency of incidence growth among the youth. According to the WHO, OA of knee joints is among five main reasons of the incapacity to work in women, and among ten - in men. OA is one of the main reasons of early incapacitation and disabilities, being second in this regard only to the ischemic heart disease (IHD) $[4,5]$.

In the USA 39 million of arthritis patients see a doctor yearly, with over 500 thousand of them being hospitalized. Further, the costs associated with medical care comprise 15 billion dollars, while the total economic losses - 65 billion dollars. Prognostic statistical data show that by 2020 the incidence of arthritis might comprise about 60 million people, i.e. almost $20 \%$ of the population, 11 million of which might become disabled, unless the situation is intervened into [6,7].

According to the official statistics of diseases registered in the health care organizations within the last several years, the statistical insights and social importance of musculoskeletal system (MSS) and connective tissue disorders in Ukraine looks as follows.

As for official statistics, 26.614,512 cases were registered in 2017 for the first time, $4.65 \%$ of which comprised the MSS and connective tissue disorders, i.e. 2878 cases per 100,000 population.

OA is the most widely spread MSS disorder in Ukraine. According to the official statistical data the OA incidence in Ukraine comprises 2200,6 cases per 100,000 population. The OA incidence in population $(6.43 \%)$ increases with age and reaches maximum values $(13.9 \%)$ in individuals over 45 years of age. The occurrence among men and women of working and retirement age also varies. In men it is $32 \%$ less (423.1), than in women (558.8). In people of working age it is 2.7 times less (338.9) than in retired individuals $(931.1)[8,9]$.

According to the National Institute for Strategic Studies of the Ministry of Health of Ukraine the share of bone fractures among all traumatic injuries comprised $86.4 \%$ in 2016 , which was equal to 3,500 patients per 100,000 population. The number of patients that were losing the working capacity reached 1,58 million people (or 3.6\% of all the population of Ukraine). The greater part of fractures was provoked by MSS disorders. The carried out analysis of fractures in adults between 18 and 75 years of age (among which the most numerous group (40\%) comprised the patients between 40 and 59 years) showed that in the vast majority of cases $(51.31 \%)$ the injuries were home accidents, the second in frequency were injuries sustained in the street $(29.98 \%$ ), while $10.18 \%$ patients sustained injuries as a result of road accidents. The most common fracture localizations were in various segments of upper and lower extremities (41.1 and 54.0\% respectively), while concomitant injuries were registered in $15.9 \%$ of cases. The most frequent fractures of upper extremities were humerus fractures $(23.1 \%)$; in addition, concerning the fractures of specified localizations, the highest frequency was characteristic of patients older than 60 , which might be due to the decrease of strength characteristics of bone tissue in patients of the indicated age group [10,11].

According to the research carried out by the National Institute for Health and Care Excellence (NICE), 2,5 million of women and 900,000 of men among the population in Ukraine are affected by osteoporosis (OP). $50 \%$ of the patients become disabled as a result of the disease, and $20 \%$ - die. Fractures comprise one of the most serious OP complications. The bone mass loss depends on the gender: in women - with the speed of $0.75-2.4 \%$ per year, and in men $-0.4-1.2 \%$. In addition, the process starts in women at the age of 35 years, while in men - after 50 years. The OP incidence among women after menopausal period comprises $14 \%$ at the age of 50-59 years, $22 \%$ - at 60-69 years of age, $39 \%$ - between 70 and 79 years of age, and $70 \%$ - at the age of 80 and over. Thus, about $80 \%$ of OP patients are women, and in people over 50 years of age, in one case of two women and in one of eight men, there is a high probability of fracture occurrence [12]. 
Given the expected increase in life expectancy within the next coming years the increase in the number of osteoporotic fracture incidence will be observed. Thus, by 2035 the number of proximal femoral fractures is expected to grow by $36 \%$ in men and by $43 \%$ in women [13].

Purpose of the research is to determine the level of the supply of the population of Ukraine with chondroprotective medicines based on the data from marketing and pharmacoeconomic analysis.

Material and methods. The current research was carried out using the system approach. The MSS incidence was analyzed based on the official statistical data. The data from the State Register of Medications, information resources and official websites of pharmaceutical companies were used for the marketing analysis. The marketing data on market prices for medications were used for the price indices analysis. The indices of price variations, liquidity and solvency adequacy were calculated to assess the accessibility of chondroprotective medications.

Research results. The complex therapy of locomotor system disorders never goes without medications with chondroprotective activity. Today the range of medications with chondroprotective activity of domestic and foreign production is fairly broadly represented in the pharmaceutical market of Ukraine $[14,15]$.

Medications used for the LMS disorders treatment must comply with the guidelines of the Unified Clinical Protocol, which is created in accordance with the Methods for the development and implementation of medical standards (unified clinical protocols) of medical aid on the evidence-based medicine principles, approved by the Order of the Ministry of Health of Ukraine of 28.09.2012 № 751 "On the creation and implementation of medical and technological documents on the medical aid standardization in the system of the Ministry of Health of Ukraine". Such organizations as NICE and SIGN (Scottish Intercollegiate Guidelines Network), as well as the National Osteoporosis Guideline Group (NOGG), being based on the evidence-based medicine principles, have determined the optimal ways of the LMS pharmacotherapy management [16].

Depending on the rate of response the medications used in the LMS disorders treatment are classified into the fast-acting and slow-acting ones. SYSADOA (Symptomatic Slow Acting Drugs for OsteoArthritis), such as glucosamine, chondroitin sulfate, diacerein, hyaluronic acid, show symptomatic effect and low toxicity (Table 1) [17, 18].

Table 1. Medications used in the LMS disorders treatment

\begin{tabular}{|l|l|}
\hline \multicolumn{2}{|c|}{ Medications that modify the symptoms } \\
\hline \multicolumn{1}{|c|}{ Fast Acting } & \multicolumn{1}{c|}{ Slow Acting } \\
\hline - Analgetics; & $\bullet$ Chondroitin sulfate; \\
- Non-steroidal anti-inflammatory drugs (NSAIDs): & - Glucosamine; \\
paracetamol (acetaminophen), ibuprofen, diclofenac, & - Glucosamine + Chondroitin sulfate; \\
celecoxib, rofecoxib, tiaprofenic acid, meloxicam, & - Soy/avocado compounds; \\
nimesulide; & - Diacerein; \\
- Narcotic agents (tramadol) & - Hyaluronic acid; \\
- Glucocorticosteroids: triamcinolone, & - Glucosaminoglycan-peptide complex; \\
betametasone & $\bullet \quad$ Extract of marine organisms \\
\hline
\end{tabular}

Development of slow acting anti-inflammatory and structurally modifying agents chondroprotectors - is the doubtless achievement of modern pharmacotherapy $[19,20]$.

The prescription of combined medications is preferred in clinical practice, which, on the one hand, allows achieving the additive effect in treatment, and increasing the treatment compliance, on the other hand. On prescription of combination medications the glucosaminoglycan synthesis by chondrocytes in increased by $96.6 \%$ compared to $32 \%$ in case of monotherapy. Application of combination medications treatment (glucosamine + chondroitin) objectively increases the number and sizes of chondrocytes per unit area of joint cartilage [21,22].

We have carried out analysis of average retail prices of chondroprotective medications, which are registered in Ukraine and are represented in pharmacy institutions. The research on the pricing policy of chondroprotective medications in Kharkiv pharmacies was conducted during the period of 01.06 to 01.072019.

The range of medications with chondroprotective activity in pharmacy chains of Kharkiv city are represented by 40 trade names (Tables 2,3 ). 
Table 2. Analysis of retail prices of monotherapy medications with chondroprotective activity in pharmacies of Kharkiv city (2019)

\begin{tabular}{|c|c|c|c|c|c|c|c|}
\hline № & $\begin{array}{l}\text { Trade name / } \\
\text { Manufacturer }\end{array}$ & $\begin{array}{l}\text { Dosage form, } \\
\text { strength, amount } \\
\text { per unit }\end{array}$ & $\begin{array}{l}\mathrm{P}_{\min } \\
\mathrm{UAH}\end{array}$ & $\mathrm{P}_{\max }, \mathrm{UAH}$ & $\Delta, \mathrm{UAH}$ & $\mathrm{C}_{\text {liq }}$ & C.s. \\
\hline 1 & 2 & 3 & 4 & 5 & 6 & 7 & 8 \\
\hline \multicolumn{8}{|c|}{ MONOTHERAPY MEDICATIONS } \\
\hline \multicolumn{8}{|c|}{ M01A X Other anti-inflammatory and antirheumatic agents, non-steroids } \\
\hline \multicolumn{8}{|c|}{ M01A X05 Glucosamine } \\
\hline 1 & $\begin{array}{l}\text { Artiflex, "Zdorovye", } \\
\text { Ukraine }\end{array}$ & $\begin{array}{l}\text { powder for oral } \\
\text { solution, } 1.5 \mathrm{~g} \text { per } \\
4.0 \mathrm{~g} \text { packet, №20 }\end{array}$ & 429 & 598 & 169 & 0,39 & 4,76 \\
\hline 2 & $\begin{array}{l}\text { Glucosamin Orion } \\
\text { Corp., Finland }\end{array}$ & $\begin{array}{l}\text { powder for oral } \\
\text { solution, } \\
1500 \text { mg per } \\
\text { pack, №20 }\end{array}$ & - & - & - & - & - \\
\hline 3 & $\begin{array}{l}\text { Glucosate, } \\
\text { "Biopharma", Ukraine }\end{array}$ & $\begin{array}{l}\text { solution for } \\
\text { injections, } \\
502,5 \mathrm{mg} \text { per } 1 \mathrm{ml} \\
\text { ampule, №5 }\end{array}$ & 287 & 368 & 81 & 0,28 & 3,04 \\
\hline 4 & $\begin{array}{l}\text { Dona, "MEDA Pharm } \\
\text { GmbH \& Co", } \\
\text { Germany }\end{array}$ & $\begin{array}{l}\text { powder for } \\
\text { oral solution, } \\
1500 \text { mg per } \\
\text { sachet, №20 }\end{array}$ & 556 & 737 & 181 & $\mathbf{0 , 3 3}$ & 5,99 \\
\hline 5 & $\begin{array}{l}\text { Dona, "MEDA Pharm } \\
\text { GmbH \& Co", } \\
\text { Germany }\end{array}$ & $\begin{array}{l}\text { solution for } \\
\text { injections, } \\
400 \mathrm{mg} / \mathrm{ml} \text {, №6 }\end{array}$ & 537 & 709 & 172 & 0,32 & 5,78 \\
\hline 6 & $\begin{array}{l}\text { Sinarta, "Farmak", } \\
\text { Ukraine }\end{array}$ & $\begin{array}{l}\text { powder for oral } \\
\text { solution, } 1,5 \mathrm{~g} \\
\text { per } 3,95 \mathrm{~g} \\
\text { sachet, №30 }\end{array}$ & 300 & 386 & 86 & 0,29 & 3,18 \\
\hline 7 & $\begin{array}{l}\text { Sinarta, "Farmak", } \\
\text { Ukraine }\end{array}$ & $\begin{array}{l}\text { solution for } \\
\text { injections, } 200 \\
\mathrm{mg} / \mathrm{ml} \text { in } 2 \mathrm{ml} \\
\text { ampoule, №5 }\end{array}$ & 391 & 558 & 167 & 0,43 & 4,40 \\
\hline \multicolumn{8}{|c|}{ M01A X25 Chondroitin sulfate } \\
\hline 8 & $\begin{array}{l}\text { Artrida, Haupt Pharma } \\
\text { Livron S.A.S, France }\end{array}$ & $\begin{array}{l}\text { solution for } \\
\text { injections, } 100 \\
\mathrm{mg} / \mathrm{ml} \text { in } 2 \mathrm{ml} \\
\text { ampoule, №10 }\end{array}$ & 398 & 527 & 129 & 0,32 & 4,29 \\
\hline 9 & $\begin{array}{l}\text { Artedja, "Fitofarm", } \\
\text { Ukraine }\end{array}$ & $\begin{array}{l}\text { solution for } \\
\text { injections, } \\
200 \mathrm{mg} \text { in } 2 \mathrm{ml} \\
\text { ampoule, №10 }\end{array}$ & 447 & 602 & 155 & 0,35 & 4,86 \\
\hline 10 & $\begin{array}{l}\text { Artedja, "Fitofarm", } \\
\text { Ukraine }\end{array}$ & emulgel, tube $40 \mathrm{~g}$ & 78,5 & 98,3 & 19,8 & 0,25 & 0,82 \\
\hline 11 & $\begin{array}{l}\text { Artiflex Chondro, } \\
\text { "Zdorovye", Ukraine }\end{array}$ & $\begin{array}{l}\text { solution for } \\
\text { injections, } \\
100 \mathrm{mg} / \mathrm{ml} \text { in } 2 \mathrm{ml} \\
\text { ampoule, №10 }\end{array}$ & 441,70 & 615,6 & 173,9 & 0,39 & 4,90 \\
\hline 12 & $\begin{array}{l}\text { Artrox, "Novofarm- } \\
\text { Biosynthes", Ukraine }\end{array}$ & $\begin{array}{l}\text { solution for } \\
\text { injections, } \\
100 \mathrm{mg} / \mathrm{ml} \text { in } \\
2 \mathrm{ml} \text { vial, №10 } \\
\end{array}$ & 388,4 & 496 & 137,6 & 0,28 & 4,10 \\
\hline 13 & $\begin{array}{l}\text { Mucosat NEO, } \\
\text { "Belmedpreparaty", } \\
\text { Republic of Belarus }\end{array}$ & $\begin{array}{l}\text { solution for } \\
\text { injections, } 200 \\
\mathrm{mg} / 2 \mathrm{ml} \text { in } 2 \mathrm{ml} \\
\text { ampoule, №10 } \\
\end{array}$ & 580 & 791 & 211 & $\mathbf{0 , 3 6}$ & 6,35 \\
\hline 14 & $\begin{array}{l}\text { Structum, Pierre } \\
\text { Fabre Medicament } \\
\text { Production, France } \\
\end{array}$ & capsules & 795 & 931 & 136 & $\mathbf{0 , 1 7}$ & 8 \\
\hline
\end{tabular}


Continuation of table 2 .

\begin{tabular}{|c|l|l|c|c|c|c|c|}
\hline 1 & \multicolumn{1}{|c|}{2} & \multicolumn{1}{|c|}{3} & 4 & 5 & 7 & 8 \\
\hline 15 & $\begin{array}{l}\text { Chondroitin Fitofarm, } \\
\text { "Fitofarm", Ukraine }\end{array}$ & $\begin{array}{l}\text { emulgel 5\% } \\
40 \mathrm{~g}\end{array}$ & 54 & 111,4 & 57,4 & 1,06 & 0,77 \\
\hline 16 & $\begin{array}{l}\text { Chondrosat, } \\
\text { "Biopharma", Ukraine }\end{array}$ & $\begin{array}{l}\text { Solution for } \\
\text { injections, } \\
100 \mathrm{mg} / \mathrm{ml} \text { in 2 ml } \\
\text { ampoule, №10 }\end{array}$ & 447 & 667 & 220 & 0,49 & 5,16 \\
\hline 17 & $\begin{array}{l}\text { Chondroflex, } \\
\text { "Ternofarm", Ukraine }\end{array}$ & $\begin{array}{l}\text { ointment, 50 mg, } \\
\text { tube 30 g }\end{array}$ & 40,3 & 59 & 18,7 & 0,46 & 0,46 \\
\hline 18 & $\begin{array}{l}\text { Hondra-Syla, } \\
\text { "Farmak", Ukraine }\end{array}$ & $\begin{array}{l}\text { ointment 5\% } \\
\text { tube 30 g }\end{array}$ & - & - & - & - & - \\
\hline
\end{tabular}

Note: $\mathrm{P}_{\min }-$ minimal price; $\mathrm{P}_{\max }-$ maximal price; $\Delta$ - difference between the maximal and minimal prices; $\mathrm{C}_{\text {liq }}$ - liquidity coefficient; $\mathrm{C}_{\text {a.s. }}-$ solvency adequacy coefficient; $\mathrm{UAH}$ - Ukrainian hryvnia.

Table 3. Analysis of retail prices of combination medications with chondroprotective activity in pharmacies of Kharkiv city (2019)

\begin{tabular}{|c|c|c|c|c|c|c|c|}
\hline № & Trade name / Manufacturer & $\begin{array}{l}\text { Dosage form, } \\
\text { strength, amount } \\
\text { per unit }\end{array}$ & $\begin{array}{l}\mathrm{PP}_{\min } \\
\text { UAH }\end{array}$ & $\begin{array}{l}\mathrm{PP}_{\max } \\
\mathrm{UAH}\end{array}$ & $\begin{array}{l}\Delta \Delta, \\
\mathrm{UAH}\end{array}$ & $\mathrm{CC}_{\text {liq }}$ & $\mathrm{CC}_{\text {a.s. }}$ \\
\hline 1 & 2 & 3 & 4 & 5 & 6 & 7 & 8 \\
\hline \multicolumn{8}{|c|}{ M01A X20** Combinations } \\
\hline \multicolumn{8}{|c|}{ Chondroitin sulfate + Glucosamine + Methylsulfonylmethane } \\
\hline 1 & $\begin{array}{l}\text { Arthron TriActive, Unipharm Inc., } \\
\text { USA }\end{array}$ & $\begin{array}{l}\text { coated tablets, } \\
\text { №60 }\end{array}$ & 4456 & 6620 & 1164 & 00,36 & 44,98 \\
\hline \multicolumn{8}{|c|}{ M01B ANTI-INFLAMMATORY/ANTIRHEUMATIC AGENTS IN COMBINATION } \\
\hline \multicolumn{8}{|c|}{ M01B X Other anti-inflammatory/antirheumatic agents in combination with other drugs } \\
\hline \multicolumn{8}{|c|}{ Chondroitin sulfate + Glucosamine + Potassium diclofenac } \\
\hline 2 & $\begin{array}{l}\text { Movex Active, "Movi Health GmbH", } \\
\text { Switzerland }\end{array}$ & $\begin{array}{l}\text { coated tablets, } \\
400 \mathrm{mg}+500 \mathrm{mg} \\
+50 \mathrm{mg}, \text { №60 }\end{array}$ & 3370 & 4438 & 668 & 00,18 & 33,74 \\
\hline 3 & $\begin{array}{l}\text { Protechon Fast, Organosyn Life } \\
\text { Sciences, India }\end{array}$ & $\begin{array}{l}\text { coated tablets, } \\
400 \mathrm{mg} \\
+500 \mathrm{mg} \text {, №60 } \\
\end{array}$ & 2278 & 3335 & 557 & 00,20 & 22,84 \\
\hline \multicolumn{8}{|c|}{ Chondroitin sulfate + Glucosamine + Ibuprofen } \\
\hline 4 & Theraflex Advance, "Bayer”, Germany & $\begin{array}{l}\text { capsules, } \\
200 \mathrm{mg}+250 \mathrm{mg} \\
+100 \mathrm{mg} \text {, №60 }\end{array}$ & 2231 & 3343 & 1112 & 00,48 & 22,6 \\
\hline 5 & Artiflex Ultra, "Zdorovye”, Ukraine & $\begin{array}{l}\text { capsules, } \\
200 \mathrm{mg}+250 \mathrm{mg} \\
+100 \mathrm{mg} \text {, №60 }\end{array}$ & 1188 & 3300 & 1112 & 00,59 & 22,26 \\
\hline \multicolumn{8}{|c|}{ M09A OTHER DRUGS FOR DISORDERS OF THE MUSCULO-SKELETAL SYSTEM } \\
\hline \multicolumn{8}{|c|}{ M09A X10** Other drugs } \\
\hline \multicolumn{8}{|c|}{ Chondroitin sulfate + Glucosamine } \\
\hline 6 & $\begin{array}{l}\text { Chondroitin Complex, "Fitofarm", } \\
\text { Ukraine }\end{array}$ & $\begin{array}{l}\text { capsules, } \\
400 \mathrm{mg}+500 \mathrm{mg} \text {, } \\
\text { №60 }\end{array}$ & 2225 & 2272 & 447 & 00,20 & 22,3 \\
\hline 7 & Theraflex, "Bayer", Germany & $\begin{array}{l}\text { capsules, } \\
400 \mathrm{mg}+500 \mathrm{mg} \text {, } \\
\text { №60 }\end{array}$ & 2284 & 4407 & 1123 & 00,43 & 33,2 \\
\hline 8 & Hondra-Syla, "Farmak”, Ukraine & $\begin{array}{l}\text { capsules, } \\
200 \mathrm{mg}+250 \mathrm{mg} \text {, } \\
\text { №60 }\end{array}$ & 1167 & 2248 & 881 & 00,49 & 11,92 \\
\hline 9 & Hondra-Syla, “Farmak”, Ukraine & $\begin{array}{l}\text { ointment, } 5 \%, \\
\text { tube } 30 \mathrm{~g}\end{array}$ & 557,7 & 775 & 117,3 & 00,29 & 00,62 \\
\hline 10 & $\begin{array}{l}\text { Movex Comfort, "Movi Health } \\
\text { GmbH", Switzerland }\end{array}$ & $\begin{array}{l}\text { coated tablets, } \\
400 \mathrm{mg} \\
+500 \mathrm{mg} \text {, №60 }\end{array}$ & 2232 & 3339 & 1107 & 00,46 & 22,64 \\
\hline 11 & $\begin{array}{l}\text { Arthron Complex, Unipharm Inc., } \\
\text { USA }\end{array}$ & $\begin{array}{l}\text { coated tablets, } \\
500 \mathrm{mg} \\
+500 \mathrm{mg} \text {, №60 } \\
\end{array}$ & 2243 & 3350 & 1107 & 00,44 & 22,75 \\
\hline
\end{tabular}


Continuation of table 3 .

\begin{tabular}{|c|c|c|c|c|c|c|c|}
\hline 1 & 2 & 3 & 4 & 5 & 6 & 7 & 8 \\
\hline 12 & Artiflex Plus, "Zdorovye”, Ukraine & $\begin{array}{l}\text { coated tablets, } \\
500 \mathrm{mg} \\
+500 \mathrm{mg} \text {, } \\
1000 \mathrm{mg} \text {, №60 }\end{array}$ & 2261 & 4422 & 1161 & 00,61 & 33,16 \\
\hline 13 & Artedja Complex, "Fitofarm”, Ukraine & $\begin{array}{l}\text { capsules, } \\
400 \mathrm{mg} \\
+500 \mathrm{mg} \text {, №60 }\end{array}$ & 2256 & 3313 & 557 & 00,22 & 22,64 \\
\hline 14 & $\begin{array}{l}\text { Protechon, Organosyn Life Sciences, } \\
\text { India }\end{array}$ & $\begin{array}{l}\text { coated tablets, } \\
400 \mathrm{mg} \\
+500 \mathrm{mg} \text {, №60 }\end{array}$ & 1192 & 4402 & 2210 & 11,09 & 22,75 \\
\hline 15 & $\begin{array}{l}\text { Artiflex Glucosamine+Ibuprofen, } \\
\text { "Zdorovye", Ukraine }\end{array}$ & $\begin{array}{l}\text { cream, tube } \\
20 \mathrm{~g}, 40 \mathrm{~g}, 100 \mathrm{~g}\end{array}$ & 885 & 1146 & 661 & 00,71 & 11,07 \\
\hline 16 & $\begin{array}{l}\text { Alflutop Chondroitin Sulfate, S.C. } \\
\text { "Biotehnos" S.A., Romania }\end{array}$ & $\begin{array}{l}\text { solution for } \\
\text { injections, } 1 \% 1 \mathrm{ml} \\
\text { ampoule, №10 }\end{array}$ & 6689 & 7779 & 990 & 00,13 & 66,80 \\
\hline 17 & $\begin{array}{l}\text { Arthron TriActive Chondroitin sulfate } \\
+ \text { Glucosamine + } \\
\text { Methylsulfonylmethane, Unipharm } \\
\text { Inc., USA }\end{array}$ & $\begin{array}{l}\text { coated tablets, } \\
400 \mathrm{mg}+ \\
500 \mathrm{mg}+ \\
300 \mathrm{mg}, \text { №60 }\end{array}$ & -- & -- & -- & -- & -- \\
\hline 18 & $\begin{array}{l}\text { Osteoartheaze Active Plus } \\
\text { Glucosamine + Chondroitin sulfate } \\
\text { with other API, Australian Pharm. } \\
\text { Manuf. Pty Ltd, Australia }\end{array}$ & $\begin{array}{l}\text { coated tablets, } \\
750 \mathrm{mg}+ \\
150 \mathrm{mg} \text {, №60 }\end{array}$ & -- & $-\overline{-}$ & -- & -- & -- \\
\hline 19 & $\begin{array}{l}\text { Rumalon Glucosaminoglycan- } \\
\text { peptide complex, C.O. Rompharm } \\
\text { Company S.R.L., Romania }\end{array}$ & $\begin{array}{l}\text { solution for } \\
\text { injections, } 2,5 \\
\text { mg/ml in } 1 \text { ml } \\
\text { ampoule, №10 }\end{array}$ & 11096 & 11100 & 74 & $\mathbf{0 0 , 0 0 3}$ & 110,18 \\
\hline \multicolumn{8}{|c|}{ Glucosamine hydrochloride with other APIs } \\
\hline 20 & $\begin{array}{l}\text { Osteoartheaze, Australian Pharm. } \\
\text { Manuf. Pty Ltd, Australia }\end{array}$ & $\begin{array}{l}\text { coated tablets, } \\
750 \mathrm{mg}, \text { №30 }\end{array}$ & 668 & 3344 & 2276 & 44,06 & 11,91 \\
\hline 21 & $\begin{array}{l}\text { Osteoartheaze Active, Australian } \\
\text { Pharm. Manuf. Pty Ltd, Australia }\end{array}$ & $\begin{array}{l}\text { coated tablets, } \\
750 \mathrm{mg} \text {, №60 }\end{array}$ & -- & -- & -- & -- & -- \\
\hline 22 & $\begin{array}{l}\text { Osteoartheaze Max, Australian Pharm. } \\
\text { Manuf. Pty Ltd, Australia }\end{array}$ & $\begin{array}{l}\text { coated tablets, } \\
750 \mathrm{mg} \text {, №60 }\end{array}$ & -- & -- & -- & -- & -- \\
\hline
\end{tabular}

Note: $\mathrm{P}_{\min }$ - minimal price; $\mathrm{P}_{\max }$ - maximal price; $\Delta$ - difference between the maximal and minimal prices; $\mathrm{C}_{\text {liq }}$ - liquidity coefficient; $\mathrm{C}_{\mathrm{a} . \mathrm{s} .}$ - solvency adequacy coefficient; $\mathrm{UAH}$ - Ukrainian hryvnia.

The analysis of the range of medications with chondroprotective activity by dosage form has shown that out of 40 trade names of medications: 12 items are produced as coated tablets (30\%), 11 drug items - as solutions for injections (27.5\%), 7 - as capsules (17.5\%), 6 medications - as soft dosage forms (15\%), and 4 items - as powders for oral administration (10\%).

The results of the analysis have shown that the top market share of chondroprotective medications in Ukrainian market belongs to the foreign drugs $(52.5 \%)$, while domestic medications occupy $47.5 \%$. In general, the nomenclature of Ukrainian medications is provided by 6 companies. The leaders of domestic production are 3 pharmaceutical companies, producing 5 names of medications each (12.5\% each): Pharmaceutical company "Zdorovye" (Kharkiv), PrJSC "Fitofarm" (Bakhmut, formerly Artemivsk, Donetsk region), JSC "Farmak" (Kyiv). Among the foreign producers the greatest shares belong to: Germany and Austria - 10\% each, and the USA - 7.5\%. France, India, Switzerland and Romania occupy 5\% each respectively.

We have carried out the analysis of the prices of chondroprotective medications liquidity by calculating the liquidity coefficient $C_{\text {liq }}$ :

where $P_{\max }-$ maximal price;

$$
C_{\text {liq }}=\frac{P_{\max }-P_{\min }}{P_{\min }},
$$

$P_{\min }$ - minimal price.

The solvency adequacy coefficient was calculated: 


$$
C_{a . s}=\frac{\overline{P_{r}}}{W_{a . w}} \times 100 \%,
$$

$C_{\text {a.s. }}-$ solvency adequacy coefficient;

$P_{r}-$ average drug retail price per a certain period of time (month, quarter, year);

$W_{\text {a.w. }}$ - average wages per a certain period of time (month, quarter, year); the data of the average wages in June 2019 - 10,783 UAH - were used in the current research.

The results of the analysis have shown that in the group of monotherapy medications M01A X25 Chondroitin sulfate as solutions for injections the most affordable one is Artrox (Ukraine) $388,40 \mathrm{UAH}\left(\mathrm{C}_{\mathrm{a} . \mathrm{s}}=4,1\right)$, while Mucosat NEO (Republic of Belarus) is the most expensive one -580 $\mathrm{UAH}\left(\mathrm{C}_{\text {a.s. }}=6,35\right)$. There is only one item in the form of capsules - Structum capsules, $500 \mathrm{mg}$, №60 (France) $-795 \mathrm{UAH}\left(\mathrm{C}_{\mathrm{a} . \mathrm{s} .}=8\right)$ in the abovementioned group.

The most affordable monotherapy medication from the M01A X05 Glucosamine group in the form of solutions for injections is Glucosate (Ukraine) - $287 \mathrm{UAH}\left(\mathrm{C}_{\text {a.s. }}=3,04\right)$. Among the powders for oral solutions preparation the most affordable one is Sinarta (Ukraine) 1,5 g per 3,95 g sachet, №30 $-300 \mathrm{UAH}\left(\mathrm{C}_{\text {a.s. }}=3,18\right)$, while the least affordable one is Dona (Germany) $-556 \mathrm{UAH}\left(\mathrm{C}_{\text {a.s. }}=5,99\right)$.

Combination medications with chondroprotective activity (M09A) are represented in the form of coated tablets (30\% of the total number of trade names) and capsules (15\%), soft dosage forms and solutions for injections (5\% each respectively). Among combination medications in the form of coated tablets the most affordable ones are foreign medications Protechon (India) №60 - 192 UAH $\left(\mathrm{C}_{\text {a.s. }}=\right.$ $2,75)$ and Osteoartheaze (Australia) №30 - $68 \mathrm{UAH}\left(\mathrm{C}_{\text {a.s. }}=1,91\right)$. Among domestic medications the most affordable one is Hondra-Syla (Ukraine) №60 - 167 UAH $\left(\mathrm{C}_{\text {a.s. }}=1,92\right)$. The most expensive foreign medication in this category is Rumalon (Romania) in the form of solutions for injections $1096 \mathrm{UAH}\left(\mathrm{C}_{\text {a.s. }}=10,18\right)$. Among the ointments the most affordable medication is Hondra-Syla (Ukraine) $-57,7 \mathrm{UAH}\left(\mathrm{C}_{\text {a.s. }}=0,62\right)$.

Analysis of the range of medications with chondroprotective activity has shown that the largest share is represented by combination chondroprotective medications, containing the combination of chondroitin sulfate with glucosamine, which occupy 35\% (14 trade names) of the market. Medications that contain active ingredients from the group of NSAIDs comprise $10 \%$ (4 trade names), and other medications $-10 \%$. Monotherapy medications with Chondroitin sulfate as an active ingredient comprise $27,5 \%$ (11 trade names), while monotherapy medications with Glucosamine as an active ingredient $-17,5 \%$ (7 trade names).

\section{Conclusions.}

1. The LMS disorders comprise one of the main reasons for the incapacity to work and physical disability of population. These disorders cause the impairment of quality of life and carry significant financial treatment expenses.

2. The Unified Clinical Protocol of primary, secondary (specialized) care allows doctors to control the state of a patient at any stage of illness and guarantees the effective treatment and prophylaxis of LMS disorders. At the same time, the long-term treatment with chondroprotective medications according to the doctor's indications might show the desired effect and allow improving the patient's quality of life.

3. Analysis of the range of chondroprotective medications has shown that the majority of drugs are represented by coated tablets $(30 \%)$ and solutions for injections $(27.5 \%)$. In addition, the majority of medications $(52.5 \%)$ are of foreign production. analysis of the range of medications with chondroprotective activity that the greatest share is represented by combination medications that contain the combination of chondroitin sulfate with glucosamine - 35\%. Monotherapy medications from the group M01AX25 Chondroitin sulfate comprise $27.5 \%$, and from the group M01AX05 Glucosamine $-17.5 \%$.

4. The analysis of price indices (price variations, liquidity, solvency adequacy) of chondroprotective medications, present in the pharmacies of Kharkiv city, has been carried out. The most affordable medications are Artrox (M01AX25) as solution for injections - 388,40 UAH $\left(\mathrm{C}_{\text {a.s. }}=\right.$ $4,1)$ and Glucosate (M01AX05) as solution for injections - 287 UAH $\left(\mathrm{C}_{\text {a.s. }}=3,04\right)$, Sinarta (M01A $\mathrm{X} 05)$ as a powder for oral solution $-300 \mathrm{UAH}\left(\mathrm{C}_{\mathrm{a} . \mathrm{s} .}=3,18\right)$.

Combination medications are mainly represented in the form of tablets (30\%) and capsules $(15 \%)$. The most affordable by price among the foreign medications are coated tablets Protechon (M01B X) №60 - 192 UAH $\left(\mathrm{C}_{\mathrm{a} . \mathrm{s} .}=2,75\right)$. Among domestic medications the most affordable one is Hondra-Syla (M09A X10**) №60 - 167 UAH $\left(\mathrm{C}_{\text {a.s. }}=1,92\right)$. 


\section{REFERENCES}

1. Державний реєстр лікарських засобів України [Електронный ресурс]. - Режим доступу: http://www.drlz.kiev.ua/

2. Денисюк В I, Денисюк О В. Остеоартроз: стандарти діагностики та лікування за результатами доказової медицини // Український медичний часопис. - 2012. - №1 (87). - С. 91-95.

3. Коваленко В.М., Борткевич О.П. Остеопороз і біль: стан проблем // Біль. Суглоби. Хребет. - 2011. № 1. - C. 41-44.

4. Henrotin Y., Marty M., Mobasheri A. What is the current status of chondroitin sulfate and glucosamine for the treatment of knee osteoarthritis? // Maturitas, 2014. - Vol 78 p. 184-187.

5. Hochberg M., Chevalier X., Henrotin Y. et al. (2013) Symptom and structure modification in osteoarthritis with pharmaceutical-grade chondroitin sulfate: What's the evidence? Curr. Med. Res. Opin., 29: 259-267.

6. Лыгина, Е. В. Хондропротекторы в лечении остеоартроза / Е. В Лыгина // Современная ревматология. - 2012. - № 2. - С. 59-63.

7. Clegg D.O., Reda D.J., Harris C.L. et al. Glucosamine, chondroitin sulfate, and the two in combination for painful knee osteoarthritis. N Engl J Med 2006; 354 (8):795-808.

8. Князькова И. И. Лечение остеоартроза / И. И. Князькова // Здоров'я України. 2016. № 2. С. 56-58.

9. Бурьянов А.А. Боль в суставах. Остеоартроз. Диагностика и лечение на современном этапе // Практикуючий лікар. - 2014. - №4. - С. 18-24.

10. Andreopoulou P. Management of postmenopausal osteoporosis / P. Andreopoulou, R. S. Bockman // Ann. Rev. Med. 2015. Vol. 14. P. 329-342.

11. Корж Н.А. Распространенность переломов костей и результаты их лечения в Украине (клиникоэпидемиологическое исследование) / Корж Н.А., Герасименко С.И., Климовицкий В.Г., Лоскутов А.Е., Романенко К.К., Герасименко А.С., Коломиец Е.Н. // Медицинские новости. - 2011. - Вып. 7. - С. 37-44.

12. Bone cell mechanosensitivity, estrogen deficiency, and osteoporosis / Klein-Nulend J., van Oers R. F., Bakker A. D. et al. // J. Biomech. 2014. P. 26-30.

13. Алексеева Л.И. Хондроитин сульфат в лечении остеоартроза // Новости медицины и фармации. 2008. - №15 (252). - С. 23-25.

14. Носівець Д. С. Фармакологія хондропротекторів (Огляд фармацевтичного ринку України) / Д. С. Носівець // Вісник проблем біології і медицини. 2013. Вип. 4(1). С. 57-63.

15. CPMP/QWP/604/96. - Note for Guidance on Quality of Modified Release Products: A: Oral Dosage Forms. B: Transdermal Dosage Forms. Section 1 (Quality).

16. Про створення та впровадження медико-технологічних документів зі стандартизації медичної допомоги в системі Міністерства охорони здоров'я України [Електронний ресурс]: наказ МО3 України від 28.09.2012 р. №751 - Режим доступу :

17. Bruyere O., Burlet N., Delmas P. et al. Evaluation of Symptomatic Slow-Acting Drugs in Osteoarthritis Using the GRADE System. BMC Musculoskelet Dis 2008; 16 (9):165.

18. Алексеева Л.И. Симптоматические препараты замедленного действия при лечении остеоартроза. Cons med 2009;11 (9):100 4.

19. Проценко Г.А. Рациональная терапия остеоартроза // Новости медицины и фармации. - 2008. - № 8(242). - c. 3-4.

20. Lane N.E., Brandt K., Hawker G. et al. (2011) OARSI-FDA initiative: Defining the disease state of osteoarthritis. Osteoarthr. Cartil., 19: 478-482.

21. Зупанець I.А. Феномен синергізму сучасних хондропротекторів // Новости медицины и фармации. 2009. - № 15 (289). - С. 9.

22. Коструб А.А., Засаднюк И.А., Канюс С.М. Применение иньекционного глюкозамина сульфата в комплексной терапии пациентов с остеоартрозом // Травма. - 2013. - Т.14, № 15. - С. 32-35.

23. Мамчур В.И. Фармакологія хондропротекторів. Можливості медикаментозного захисту синовіальних суглобів і хрящової тканини / В.И. Мамчур, Д.С. Носивец // Фармацевтичний кур'єр. 2013. № 5. C. 22-27. 